\title{
LINKING CRISIS AND EMERGENCY MANAGEMENT IN STRATEGIC MANAGEMENT PROCESS OF NGOS IN GAZA STRIP
}

\author{
Amina Ata Abed Elaty Elzaanin1*, Ayi Ahadiat1, Habibulla Jimad1 \\ ${ }^{1}$ Faculty of Economics and Bussines, University of Lampung,Indonesia \\ *amina.elzaanin@gmail.com
}

\begin{abstract}
NGOs play an important and clear role in development and relief programs in Gaza Strip. Due to the political conditions that Gaza Strip is going through and to the limited services which are presented by the government in Gaza Strip. Although of the remarkable role of these organizations, they face problems and shortcomings in management in times of crises and emergencies. This study aims to show how to link crisis and emergency management to the process of strategic management of NGOs in Gaza Strip. This study sheds lights on some aspects of the functions of strategic management processes and also it investigates some aspects of the possibility of NGOs dealing with disasters in Gaza Strip. The descriptive analytical method was used to achieve the objectives of the study. The researcher used a questionnaire to collect data. The study sample consisted of 120 employees working in NGOs. The current study shows some weakness in crisis and emergency management. Furthermore, there is a positive relationship between the formulation, implementation and evaluation of strategy and crisis and emergency management for NGOs in Gaza Strip. The results showed that there is a statistically significant relationship at the significance level $(a \leq 0.05)$ between strategic management processes and crisis and emergency management in NGOs in Gaza Strip
\end{abstract}

Keywords: Crises Management, Emergency Management, Strategic Management Process, Strategy Formulation, Strategy Implementation, Strategy Evaluation, NGOs, Gaza Strip.

Copyright (C) 2020, International Journal of Economics, Business and Entrepreneurship | IJEBE | FEB-UNILA

\section{INTRODUCTION}

The era in which we live full of crises and disasters, it is no longer asked whether the crisis will come or not? The question becomes what organizations shall do when a crisis or disaster come. Crisis and disasters are sudden unexpected changes in the internal environment. Without anticipating their emergence, or the opportunity to avoid them, they contain the seeds in them. Success and the root of failure, the organization that is the most ready and able to overcome a crisis or disaster, is characterized by the availability of more opportunities for succeed in crisis management and overcome the negative, and therefore the ability to control the crisis path."Crisis and emergency management has become an important and a main feature of organizations that exist appear in conflict and war zones. The crisis is considered a major threat to the organization's continuity and survival in addition, the ability to continue providing its services to the community. The organization's success in managing crises and emergencies is a strong motivation for its survival as it gains reputation and confidence in society. If the organization is not able to deal with crises through effective management of various stages of the crisis, so its image in society will be at stake. Emergency plans have a prominent role in facing crisis and emergencies. Along with the organization must develop integrated and prepared plan in advance to confront crises and to limit the requirements for crisis and emergency management through 
preparation, leadership, coordination, collective decisions, building a work team and a qualified cadre capable of how to face crises. Also, there is a prior strategy on how to tool the crisis that helps in reducing the risks and losses resulting from it if it occurs, as well as the presence of an operations room to manage the work during and after the occurrence of the crisis is one of the basic requirements for the success of crisis management" (Ali, 2014).

"Strategic management process is every manager concern as any failure in determining strategies which matches with resources and capabilities of the organization is devastating to its overall sustainability survival and growth. Companies without clear strategies may achieve some success in the short run, but as soon as competitive conditions stiffen or an anticipated threat arises, they usually "hit the wall "and fold" (Phiri, Ngandwe, Mukutu, Moono and Kapapi,2019). Therefore, the need for strategic planning processes has increased in its three stages (strategy formulation-strategy implementation-strategy evaluation). Strategic planning is an important element for the success and survival of the organization. In the absence of a component of strategic planning processes, the organization will become unable to effectively manage and it loses its available resources as well as it will not achieve the set goals.

Due to the increasing of disasters and crises in Gaza Strip, the responsibility for managing NGOs must be enhanced. Additionally, the need to continuously improve their performance and working methods become a necessity. It requires a lot of preparation before, during and after a crisis or disaster, to ensure the minimum of the negative effects that may result. Which requires raising the level of preparedness to confront these crises and disasters through prior preparation and long-term strategic planning, the provision of qualified human cadres and the systems through which these emergency crises can be addressed. Organizations in Gaza strip lack emergency plans within the strategic plans where work is random and disorganized in times of crisis and emergency. This is a burden for the organization and it wastes resources and time. Study of Al-Barei (2018) also indicated that the most important main factors that affected the relief work during the 2014 aggression are the lack of a clear strategy for the institutions working in relief operations, the lack of a clear methodology for joint coordination between the relief sectors and the weakness of the infrastructure of these sectors. Below, we explain an overview of Gaza Strip, its crisis, and the role of non-governmental organizations in light of the aggravation of the ongoing crises.

Based on the background above, this study specifically seeks to answer the following questions:

1. How can strategy formulation correlate to crisis and emergency management of NGOs in Gaza Strip?

2. What is the relationship between strategy implementation and crisis and emergency management of NGOs in Gaza Strip?

3. What is the correlation between strategy evaluation and crisis and emergency management of NGOs in Gaza Strip?

\section{METHODS}

The researchers used descriptive analytical method which tries to "linking crisis and emergency management in strategic management process of NGOs in Gaza strip" and descriptive analytical method tries to compares and explains and assesses to reach the generalizations meaningful increases the stock of knowledge on the subject, has been collecting data from sources primary and secondary sources 


\section{Study population and sampling}

The study target population in this study is (874) NGOs in the Gaza Strip distributed in five governorates (North, Gaza, Deir El-Balah, Khan Younis, Rafah). And the study sample amounted to 120 employees, and the following is the distribution of the study sample according to personal data and information about the organization.

A purposive sample is selected according to the purpose of the researcher. Who aims to get answers from participants that have experience crisis training and have a background about crisis management. Respondents are employees of NGOs in Gaza Strip who have experience working during crises and emergencies as well as those who have experience working in the field of relief. The research sample consists of 120 workers who were selected through 15 effective organizations and have sufficient experience in the field of crises and emergencies, considering that the maximum number of workers in one organization is 8 workers. The researcher does not know the detailed list of workers' identities, so the researcher will provide questionnaires to the respondents who are easily accessible and wish to be participants.

\section{Research instrument}

The first-dimension instrument is about Strategy formulation (8) statements. The second dimensions of the instrument which Strategy Implementation (6) statements. The thirddimension instrument is about Strategy Evaluation (6) statements The fourth-dimension instrument is about Crisis and Emergency Management (12) statements.

Table 1. Research Instrument

\begin{tabular}{|c|c|}
\hline Dimension & Number of paragraphs \\
\hline First dimension: Strategy formulation. & 8 \\
\hline Second dimension: Strategy Implementation. & 6 \\
\hline Third dimension: Strategy Evaluation. & 6 \\
\hline $\begin{array}{l}\text { Fourth dimension: Crisis and Emergency } \\
\text { Management. }\end{array}$ & 12 \\
\hline Total questionnaire paragraphs & 32 \\
\hline
\end{tabular}

A five-point Likert scale of agreement was used for measurement, running from "Strongly Agree" to "Strongly Disagree", with a Neutral category for scale midpoint.

\section{Validity and reliability assessment:}

The study adopted Cronbach's Alpha to measure the internal consistence reliability of the questionnaire. The results showed that Cronbach's $\alpha$ value for all dimensions were $\alpha \leq 0.05$. It indicated that the design of the questionnaire had a high internal consistency.

\section{Statistical procedures:}

Several statistical tools were used for data analysis and hypotheses testing, including reliability Correlation using Cronbach's alpha, Pearson Correlation Coefficient, and Kolomogrov smernov.

\section{RESULTS AND DISCUSSION}

T test used to examine the dimensions and hypotheses. The results of the analysis are shown in table 2. 
Table 2. T test for dimensions

\begin{tabular}{llcccccc}
\hline No. & \multicolumn{1}{c}{ Dimensions } & Mean & $\begin{array}{c}\text { Standard } \\
\text { deviation }\end{array}$ & $\begin{array}{c}\text { Relative Weight } \\
\mathbf{\%}\end{array}$ & T Test & P-Value & Rank \\
\hline $\mathbf{1}$ & Strategy formulation. & 3.48 & 1.03 & 69.6 & 5.113 & $0.000^{*}$ & 1 \\
\hline $\mathbf{2}$ & Strategy Implementation. & 3.44 & 0.97 & 68.8 & 4.985 & $0.000^{*}$ & 2 \\
\hline $\mathbf{3}$ & Strategy Evaluation. & 3.30 & 1.04 & 65.9 & 3.135 & $0.000^{*}$ & 4 \\
\hline $\mathbf{4}$ & $\begin{array}{l}\text { Crisis and Emergency } \\
\text { Management }\end{array}$ & 3.30 & 1.02 & 66.1 & 3.260 & $0.000^{*}$ & 3 \\
\hline
\end{tabular}

As results show, the p- value equals 0.000 , which is less than 0.05 . This indicates that the grand average degree of responses to all fourth dimensions has increased the degree of neutrality and, hence, shows approval of the sample respondents to the dimensions. The analysis shows that Strategy formulation dimension has the first rank in terms of importance, followed by Strategy Implementation, followed by Crisis and Emergency Management followed by Strategy Evaluation.

The hypotheses test showed that, there is correlation with statistical significance between Strategy (formulation, implementation, Evaluation) and crisis and emergency management of NGOs in Gaza strip, where (P-Value) is less than 0.05. This finding is shown in table 3.

Table 3. Hypotheses Test

\begin{tabular}{lcc}
\hline \multirow{2}{*}{ Dimensions } & \multicolumn{2}{c}{ crisis and emergency management } \\
\cline { 2 - 3 } & Pearson Correlation & P-Value \\
\hline Strategy formulation & 0.82 & $0.000^{*}$ \\
\hline Strategy Implementation & 0.88 & $0.000^{*}$ \\
\hline Strategy Evaluation & 0.87 & $0.000^{*}$ \\
\hline
\end{tabular}

This confirms that whenever there is a link between the operations of strategic management and crisis and emergency management of NGOs in Gaza Strip, the possibilities of effective crisis management increase, as the organization with this link becomes ready and able to be prepared to deal with any future crisis.

\section{CONCLUSION}

The results showed that there is a statistically significant relationship at the significance level ( $a \leq 0.05$ ) between strategic management processes (formulation of strategy) for the organization and crisis and emergency management in NGOs in Gaza Strip. This confirms that whenever there is a formulation of strategies in the organization, the possibilities of effective management of crises and emergencies increase. Through the formulation of the strategy, the organization develops the vision, mission and goals. Thus, this process supports its readiness to deal with crises and emergencies.

The results showed that there is a statistically significant relationship at the significance level $(a \leq 0.05)$ between strategic management processes (implementation of the strategy) of the organization and crisis and emergency management in NGOs in Gaza Strip. This confirms that whenever there is an implementation of strategies in the organization, the possibilities of effective management of crises and emergencies increase. In the process of implementing strategies, the organization allows the organization to develop and use information systems, prepare annual and monthly budgets, train the working staff and improve its performance. Thus, the organization can, through this process, be prepared to deal with crises and emergencies at what any time. 
The results showed that there is a statistically significant relationship at the significance level $(a \leq 0.05$ ) between strategic management processes (strategy evaluation) for the organization and crisis and emergency management in NGOs in Gaza Strip. This confirms that whenever there is an evaluation of strategies in the organization, the possibilities of effective crisis management increase. In the process of evaluating strategies, the organization is able to evaluate its performance and review the internal and external environment, thus showing its readiness to deal with crises and emergencies if they occur.

\section{REFERENCE}

Anand, P. (2005). Getting infrastructure priorities right in post-conflict reconstruction, Research Paper, UNU-WIDER, United Nations University (UNU). https://www.wider.unu.edu/sites/default/files/rp2005-42.pdf. Accessed on 5 Dec 2020.

Al-Barei, Dima Ziad. (2018). Realities and Challenges of Relief Operation in Shelters During 2014 Aggression on Gaza from the Beneficiaries and Service Providers Perspective (Case Study Beit Hanoun Area). Unpublished MA Thesis, Islamic University - Gaza, Palestine.

Al-Najjar, A. T. K. (2018). Participation, opportunities, and challenges faced by NGOs in managing the health sector crisis (Doctoral dissertation, The Islamic University-Gaza).

Al-Marefa. (2019). Statistics of the aggression on the Gaza Strip. www.marefa.org. Accessed on 10 July 2021.

Al Mezan Center for Human Rights. (2018). The reality of economic, social and cultural rights in the Gaza Strip during 2017, Palestine

Bryson, J. M., \& Alston, F. K. (2010). Creating and implementing your strategic plan: A workbook for public and nonprofit organizations (Vol. 1). John Wiley \& Sons.

Britannica. (2012). "Blockade of Gaza Strip". www.britannica.com. Accessed on 10 January 2021.

Chomsky, N., \& Papp, I. (2013). Gaza in crisis: reflections on Israel's war against the Palestinians. Haymarket books.

Cohen, L., Manion, L., \& Morrison, K. (2007). Research Methods in Education. New York: Routledge. Code of conduct coalition. (2008). The Palestinian NGOs code of conduct. Palestine.

Dr. A. M, Mannion. (2003). The Environmental Impact of War \& Terrorism Directory of Foreign Associations in the Gaza Strip - Studies and Research Department - General Administration of Public Affairs and NGOs - Ministry of Interior, Gaza. (January, 2020).

Debabrata Mondal, Sarthak Chowdhury\& Debabrata Basu. (2015). Role of Non-Governmental Organization in Disaster Management. Visva Bharati University.

David Lewis. (2010). Nongovernmental Organizations, Definition and History. The London School of Economics and Political Science.

Efrat, E. (2006). The West Bank and Gaza Strip: A geography of occupation and disengagement. Routledge.

Farazmand, Ali. (2014). Crisis and Emergency Management: Theory and practice. CRC press.

Fengler, W., A. Ihsan, \& K. Kaiser. (2008). Managing post-disaster reconstruction finance International experience in public financial management. World Bank Publications. Washington DC: World Bank.

Farhad Analoui\& Akram Samour. (2012). Strategic management: the case of NGOs in Palestine.

David, F., \& David, F. R. (2016). Strategic management: A competitive advantage approach, concepts and cases. Florence: Pearson-Prentice Hall.

Haris Hamidovic. (2012). An Introduction to Crisis Management. Independent

Researcher.

Habib Abu Zayed. (2015). Requirements of disaster management, the level of its success in the Gaza Strip and the Palestinian Ministry of Interior and National Security role in facing disasters. Master Thesis - Faculty of Commerce at the Islamic University - Gaza.

John M. Bryson\& Farnum K. Alston. (2005). Creating and Implementing Your Strategic Plan.

Koushafard, Shirin. (2013). "Strategy in Crisis Management." 
Lusia Neti Harwati. (2013). Crisis Management: Determining Specific Strategies and Leadership Style for Effective Outcomes. University of Malang.

Meyers, B. (1991). Disaster study of war. Disasters 15(4): 318-330. Moe, T.L., and P. Pathranarakul. 2006. An integrated approach to natural disaster management: Public project management and its critical success factors. Disaster Prevention and Management: An International Journal 15(3): 396-413.

Mazen. J. Al Shobaki, Youssef .M .Abu Amuna\& Samy .S. Abu Naser .(2016). The impact of top management support for strategic planning on crisis management: Case study on UNRWAGaza strip. Al- Azhar University, Gaza, Palestine.

Mondal, D., Chowdhury, S., \& Basu, D. (2015). Role of Non-Governmental Organization in Disaster Management. Research Journal of Agricultural Sciences, 6, 1485-1489.

Peter Shiras. (1996). Humanitarian Emergencies and the Role of NGOs. In: Whitman J., Pocock D. (eds) After Rwanda. Palgrave Macmillan, London. https://doi.org/10.1007/978-1349-24708-0 8.

Phiri, W., Ng'andwe, E., Mukutu, I., Moono, D., \& Kapapi, P. (2019). A critical analysis of strategic management process.

Palestinian Central Bureau of Statistics. (2020). Palestine in Figures 2019.

Rasheed, salih abed Alreda, Jalab\& Ihsan Dahsh.(2007). Strategic Manangement, Curriculum House for Publishing and Distribution, Amman.

Shakalaih, S. A. (2016). Practice in disaster management through non-Governmental Organizations (NGOs) in Gaza Strip.

Sakalasuriya, M.M., R.P. Haigh, \& D. Amaratunga. (2016). The consequences of post conflict reconstruction: A review of literature. In Proceedings of the 12th International Conference of the International Institute for Infrastructure Resilience and Reconstruction, 5-7 August 2016, University of Peradeniya, Kandy, Sri Lanka, 153-159. http://eprints.hud.ac.uk/id/eprint/ 29256/1/Maheshika.pdf. Accessed 5 Dec 2020.

Shirin Koushafard (2013). Strategy in Crisis Management. University of Tehran - Farabi Campus.

Siraj Bashir. (2016). The Role of NGOs In Community Development in Balochistan. University of Karachi.

Salem, Mohamed Ali. (2009). Strategic Management, Al-Bidaya Publishing House.

Sourani, Ghazi. (2013). Gaza Strip (1948-1993) Red Crescent Society of the Gaza Strip, Palestine.

UNISDR. (2009). United Nation International Strategy for Disaster Reduction.

UNITED NATION. (August, 2012). A report of Gaza in 2020 A livable place

World Health Organization. (2017). A strategic framework for emergency preparedness.

Wilkinson, D., \& Birmingham, P. (2003). Using Research Instruments: A Guide for Researchers. Psychology Press. 